\title{
Sources of organic matter for flatfish juveniles in coastal and estuarine nursery grounds: A meta-analysis for the common sole (Solea solea) in contrasted systems of Western Europe
}

\author{
O. Le Pape ${ }^{a, *}$, J. Modéran ${ }^{b}$, G. Beaunée ${ }^{a}$, P. Riera ${ }^{c}$, D. Nicolas ${ }^{d}$, N. Savoye ${ }^{e}$, M. Harmelin-Vivien $^{f}$, \\ A.M. Darnaude ${ }^{g}$, A. Brind'Amour ${ }^{h}$, H. Le Bris ${ }^{a}$, H. Cabral', C. Vinagre', S. Pasquaud', S. Françai,
} C. Kostecki ${ }^{a}$

\footnotetext{
a UMR 985 ESE, Agrocampus Ouest, Inra 65 rue de St Brieuc CS 8421535042 Rennes Cedex, France

${ }^{\mathrm{b}}$ Romberg Tiburon Center, San Francisco State University, 3152 Paradise Drive, Tiburon, CA 94920, USA

c UPMC Université Paris 06, UMR 7144, Station Biologique de Roscoff, Place Georges Teissier, 29680 Roscoff, France

d Irstea, UR EPBX, 50 av. de Verdun, F-33612 Cestas, France

e Observatoire Aquitain des Sciences de I'Univers, UMR 5805 EPOC, Université Bordeaux 1/CNRS, Station Marine d'Arcachon, 2, rue du Pr. Jolyet, 33120 Arcachon, France

f Institut Méditerranéen d'Océanologie (MIO), UMR CNRS 7294, Aix-Marseille Université, rue Batterie des Lions, 13007 Marseille, France

g Laboratoire ECOSYM, UMR 5119 UM2-CNRS-IRD-IFREMER-UM1, Université Montpellier 2, Place Eugène Bataillon, 34095 Montpellier, France

${ }^{\mathrm{h}}$ Ifremer, Centre de Nantes, Rue de l'île d'Yeu, B.P. 21105, 44311 Nantes, France

' Universidade de Lisboa, Faculdade de Ciências, Centro de Oceanografia, Campo Grande, 1749-016 Lisboa, Portugal
}

\author{
*: Corresponding author : Olivier Le Pape, Tel.: + 33223485531 ; fax: + 33223485535 ; \\ email address : olivier.le.pape@agrocampus-ouest.fr
}

\begin{abstract}
:
Coastal and estuarine nursery grounds are essential habitats for sustaining flatfish stocks since only these shallow and productive areas provide the high food supply that allows maximizing juvenile growth and survival in most flatfish species. However, the main organic matter sources at the basis of benthic food webs might differ drastically between estuarine nursery grounds under strong freshwater influences, where food webs are mainly supported by continental organic matter, and coastal ecosystems under limited freshwater influence, where the local marine primary production is the main source of carbon for the benthos. To better understand the links between continental inputs to the coastal zone and stock maintenance in the highly prized common sole, Solea solea (L.), we investigated the variability in the organic matter sources supporting the growth of its young-of-theyear (YoY) in five contrasted estuarine and coastal nursery grounds under varying freshwater influence. Stable isotopes of carbon and nitrogen allowed tracing the origin of the organic matter exploited by YoY soles in the very first months following their benthic settlement, i.e. when most of the juvenile mortality occurs in the species. A mixing model was run to unravel and quantify the contribution of all major potential sources of organic matter to sole food webs, with a sensitivity analysis allowing assessment of the impact of various trophic enrichment factors on model outputs. This meta-analysis demonstrated a relative robustness of the estimation of the respective contributions of the various organic matter sources. At the nursery scale, the upstream increase in freshwater organic matter exploitation by YoY soles and its positive correlation with inter-annual variations in the river flow confirmed previous conclusions about the importance of organic matter from continental origin for juvenile production. However, inter-site differences in the organic matter sources exploited for growth showed that, although freshwater organic matter use is significant in all nursery sites, it is never dominant, with especially high contributions of local primary production by microphytobenthos or saltmarsh macrophytes to juvenile sole growth in tidal nursery ecosystems. These patterns stress the need for maintaining both the intensity of freshwater inputs to the coastal zone and of local autochthonous primary production (especially that of the intertidal microphytobenthos) to preserve the nursery function of coastal and estuarine ecosystems.
\end{abstract}

Keywords: Nursery ground ; Flatfish ; Organic matter origin ; Stable isotopes ; Mixing model SIAR 


\section{Introduction}

Estuarine and coastal ecosystems play a critical role for stock maintenance in marine fish (Beck et al., 2001; Peterson, 2003). Due to their high productivity and the consequent high availability of prey for juvenile fish (Gibson, 1994; Beck et al., 2001; Le Pape and Bonhommeau, sub.), they are essential nursery habitats for many species (Beck et al., 2001; Woodland et al., 2012) and particularly flatfishes (Van der Veer et al., 2000; Le Pape et al., 2003b). Because flatfish juveniles preferentially settle in habitats that enhance their fitness (Gibson, 1994), the capacity of coastal and estuarine areas to sustain juvenile growth can greatly condition the renewal of flatfish populations (Rijnsdorp et al., 1992; Iles and Beverton, 2000). Yet, although rich and productive estuarine and coastal ecosystems favours the development of benthic invertebrates, which are suitable food for young flatfish (Gibson, 1994), the main origin of the organic matter that sustains flatfish food webs on their nursery grounds is still unclear. In estuaries, many studies (Darnaude et al., 2004ab; Leakey et al., 2008; Pasquaud et al., 2008; Vinagre et al., 2008b; Banaru and Harmelin-Vivien, 2009; Kostecki et al., 2010) pointed out a predominant incorporation of allochtonous organic matter of continental origin into juvenile flatfish food webs. However, in systems under low freshwater influence, in situ primary production can override other food sources and significantly contribute to growth in young flatfish (Kostecki et al., 2012).

Although spatio-temporal variations in the origin of the organic matter used were analysed locally in various flatfish nursery sites across the world (Darnaude, 2005; Pasquaud et al., 2008; Vinagre et al., 2011; Kostecki et al., 2010), only very few studies so far tried to quantify the relative contribution of different possible sources of organic matter to the food webs sustaining flatfish juveniles (França et al., 2012; Kostecki et al., 2012). This work aimed at filling this gap by quantitatively estimating the variability in the origin of the organic matter exploited for juvenile growth in the common sole, Solea solea (L., 1758), among five major nursery sites in Western Europe.

For this, stable isotopes analysis $(\mathrm{SIA})$, based on nitrogen $(\delta 15 \mathrm{~N})$ and carbon $(\delta 13 \mathrm{C})$ signatures of various food webs compartments, can be a powerful tool. This technique, which allows identification of trophic pathways and energy sources in varied ecosystems (DeNiro and Epstein, 1978; 1981; Peterson and Fry, 1987; Fry, 2006), has proved particularly successful in coastal and estuarine systems, where the fate of different sources of both freshwater and marine Particulate Organic Matter (POM) can be distinguished (Fry, 1999; Vander Zanden and Rasmussen, 2001; Yokoyama and Ishihi, 2008). By applying a mixing model analysis (Parnell et al., 2010) to previous measurements of the $\delta 15 \mathrm{~N}$ and $\delta 13 \mathrm{C}$ of both sole juveniles and the main sources of organic matter sustaining benthic food webs in contrasted flatfish nursery habitats spread over Western Europe, our aim was to quantify the main origin of the organic matter used for juvenile growth in S. solea across its distribution range, and the reasons for its geographic variability. More specifically, we wanted to test the now long standing hypothesis of a positive link between the freshwater POM availability related to upstream-downstream gradient and variations of river flow and its contribution to juvenile soles' food webs (Darnaude et al., 2004b; Kostecki et al., 2010), both at the intraand inter-site scales, and to investigate the influence of various environmental characteristics (i.e. freshwater discharge, tidal amplitude, total surface of inter-tidal productive mudflats) on the relative contribution of various organic matter sources to juvenile sole growth. 


\subsection{Collection of standardized data in different nursery systems}

\subsubsection{Site selection}

Such a meta-analysis required comparable and detailed stable isotopic data on young-of-theyear (YoY) soles and their potential organic matter sources from various major nursery grounds of the species, not only spread over a vast part of its geographic range, but also with contrasted environmental characteristics. Juvenile diet in $S$. solea can differ highly from site to site, following the inevitable geographic variations in the composition of the assemblages of benthic invertebrates, which are the major preys for YoY sole (Darnaude et al., 2001; Vinagre et al., 2008b; Kostecki et al., 2012). This spatial variability prevented the inclusion of intermediate trophic levels (i.e. sole's prey) in the present work. Therefore, sites with isotopic signatures $\left(\delta^{15} \mathrm{~N}\right.$ and $\left.\delta^{13} \mathrm{C}\right)$ available both for fully settled YoY soles and for all the organic matter sources potentially sustaining benthic food webs were considered for inclusion in the present comparisons. Five sites were finally retained (Fig. 1): the Mont St. Michel Bay (MSMB), in the Western English Channel, the estuaries of the Vilaine, the Charente and the Tagus rivers, spread along the Atlantic European coasts, and the prodelta of the Rhone river in the Mediterranean. These five sites have contrasted environmental characteristics (Table 1; Nicolas et al., 2010) and are representative of the variety of nursery habitats (estuaries, sheltered bays, prodeltas) colonised by the species across its geographic distribution. Environmental differences are maximal between the MSMB and the Rhone river prodelta, especially in terms of intertidal zone area and freshwater inputs (Table 1): Tidal amplitude is very low in the Mediterranean, resulting in a tidal range of only a few centimetres in front of the Rhone river mouth, which strongly contrasts with the conditions in the MSMB, where tidal range is the highest in Europe during spring tides $(15.5 \mathrm{~m})$ and the area of the intertidal zone is estimated at $250 \mathrm{~km}^{2}$ (Arbach-Le Loup et al., 2008). Moreover, while in the MSMB the few existing riverine inputs $\left(27 \mathrm{~m}^{3} . \mathrm{s}^{-1}\right)$ are rapidly diluted by the high hydrodynamics forces linked to the mega-tidal regime (Cugier et al., 2010), the Rhone river discharge into the Mediterranean $\left(1700 \mathrm{~m}^{3} \cdot \mathrm{s}^{-1}\right)$ is the main driver of the ecosystem structure in front of the river delta (Auger et al., 2010). Environmental conditions in the three other habitats investigated are intermediate both in terms of freshwater inputs and intertidal zone area.

\subsubsection{Standardization/selection of data}

Isotopic data from the five selected nursery sites were derived from previous published studies (Darnaude et al., 2004b; Kostecki et al., 2010; Modéran, 2010; Vinagre et al., 2011; Kostecki et al., 2012). In each case, the same standardized subset of $\delta^{15} \mathrm{~N}$ and $\delta^{13} \mathrm{C}$ signatures was selected to allow reliable comparisons between systems:

Ontogenic changes in diet are common in $S$. solea during the first year of life, the YOY juveniles generally shifting from epibenthic meiofauna to small benthic invertebrates during the first few months following their benthic settlement (Marchand, 1993). Therefore, to avoid any confounding patterns, isotopic signatures of sole YOY in the present meta-analysis were restricted to juveniles with comparable diets. In the common sole, the duration of the spawning season varies with the latitude (Koutsikopoulos and Lacroix, 1992, Vinagre et al., 2008a; Rochette et al., 2012), and that of the larval drift depends on the population (Koutsikopoulos et al., 1991; Savina et al., 2009; Rochette et al., 2012). Accordingly, dates for larval settlement in the species fluctuate from spring to early summer among the five selected sites. Thus, a common survey date would not systematically sample YoY at the same life stage. To standardize data among sites, only the isoptopic signatures measured in 
YoY of similar sizes (6 to $11 \mathrm{~cm}$; Table 2) captured a few months after their settlement in each site (i.e. in late spring or summer depending on the latitude) were selected for the present analysis. Thereby, all the YoY juveniles compared had approximately the same age and had all entered the phase of fast growth sole juveniles experience after their settlement in their nursery habitats. This allowed us to avoid biasing our conclusions by falsely including isotopic signatures from freshly settled post-larvae, with isotopic signatures still reflecting their pelagic life offshore (Darnaude, 2005), or from larger and older fish, with a different diet (Marchand, 1993; Kostecki et al., 2012). For the MSMB, the Tagus estuary and the Rhone river prodelta, $S$. solea juveniles' isotopic signatures were derived from YoY individuals all collected in the same year at their site of maximum abundance within the nursery habitat. In the other two nursery sites (Charente and Vilaine estuaries), two different locations were investigated along the estuary (Fig. 1), during one year only for the Charente estuary but for four different years in the Vilaine estuary. As a result, a total of 13 different sets of isotopic signatures were exploited for juveniles soles: 1 from the MSMB, 1 from the Tagus estuary and 1 from the Rhone river prodelta, 2 from the Charente estuary and 8 from the Vilaine estuary (Table 2).

Potential sources of organic matter at the base of benthic food webs are diverse in coastal and estuarine habitats (Kostecki et al., 2012). They include not only the in situ primary productions by local phytoplankton, microphytobenthos (MPB) and benthic macrophytes (MPh), but also allochtonous seawater POM (SW) brought by the currents and the freshwater POM discharged by local rivers (FW). In most cases, both the water POM and the sedimentary organic matter (SOM) available locally for the benthos in these areas result from a mix of these different sources in various proportions. It is thus difficult to identify the ultimate origin of the organic matter ingested by the benthos from the isotopic signature of these two organic matter pools. Moreover, only a fraction of the sedimentary pool is labile and the total SOM is not an acceptable sample of fraction actually consumed by the benthos (Zetsche et al., 2011). The isotopic signatures of the local SOM and water POM were therefore not taken into account in the meta-analysis. Similarly, the isotopic signature of in situ phytoplanktonic production was not included for the 3 estuarine habitats, because this biotic compartment is virtually impossible to separate from the POM of marine (SW) or freshwater (FW) origin also permanently present in estuarine waters.

For the four sources of organic matter investigated (FW, SW, MPB and MPh), the isotopic signatures used at each site were collected using two alternative procedures (Table 2); if the sources were analysed within the same year and during the same season than YoY, they were selected. If simultaneous data were not available, they were replaced by average values of time series data to take into account the potentially high temporal variability in the isotopic signatures of these sources (Table 2). Especially, because seawater POM (SW) was not often sampled simultaneously to fish collection in the ecosystems studied, its isotopic signature was derived from time-series data available either from other local surveys (Vinagre et al., 2008b) or from the French Coastal Monitoring Network SOMLIT (Service d'Observation en Milieu LITtoral; http://somlit.epoc.u-bordeaux1.fr/fr/). Benthic macrophytes isotopic signatures were not included in the analysis for the Charente estuary, as they do not represent a significant organic matter source in this nursery habitat, compared to the huge production from the intertidal microphytobenthos (Leguerrier et al., 2003; Modéran et al., 2012). Similarly, microphytobenthos was not considered a significant source of organic matter for the Rhone river prodelta, because its production in this non-tidal turbid system is considered to be very limited. Detailed sampling and analytical protocols for each site can be found in the references listed in Table 2, as well as more comprehensive details on (i) variation in the isotopic signature of the freshwater POM from different tributaries of the same area (MSMB, Kostecki et al., 2012), (ii) heterogeneous isotopic signatures from different local macrophytes species (Vinagre et al., 2011; Kostecki et al., 2012) and, more generally, (iii) variability in isotopic signatures among samples (Cloern et al., 2002). 


\subsection{Quantified estimates of organic matter sources in YoY trophic chain}

The contributions of each organic matter source to YoY sole production in the five nursery habitats studied were quantified using the $R$ ( $R$ Development Core Team, 2009) package SIAR (SIA in R) for mixing model analysis (Parnell et al., 2010). The use of mixing models is necessary when dealing with more sources (in the present case, four) than the number of elements analysed (in the present case, two: $\delta^{15} \mathrm{~N}$ and $\delta^{13} \mathrm{C}$ ). In this case, only this kind of approach can provide the user with the ranges of possible contribution for all sources that could explain the isotopic signatures of the consumer considered. Inputs to SIAR mixing model for each element $\left(\delta^{15} \mathrm{~N}\right.$ and $\left.\delta^{13} \mathrm{C}\right)$ are the isotopic signatures of all the organic matter sources investigated with their associated standard errors, replicates samples of consumer isotopic signatures and the trophic enrichment factors (TEF), i.e. the differences in $\mathrm{C}$ and $\mathrm{N}$ isotopic signatures between consumers and their diets (Minagawa and Wada, 1984), for the food webs studied with their standard errors. In SIAR, the application of Bayesian methods to the mixing model allows accounting for both uncertainty (i.e. the variation associated to both the variability of the isotopic signature of the sources and that of the TEFs) and variability (i.e. the variation linked to inter-individual differences in isotopic signatures in the consumer) when generating the probability estimates of the source contributions.

Uncertainty in $\delta^{15} \mathrm{~N}$ and $\delta^{13} \mathrm{C}$ isotopic signatures for each organic matter source was calculated from the datasets. Both mean and standard error of isotopic signatures for sources and individual YoY isotopic signatures (from 5 to 51 fish per sample, Table 2) were included in SIAR. A sensitivity analysis was also performed to analyse the impact of different TEFs on model outputs. The trophic level of YoY sole being close to 3 (Darnaude et al., 2001; Kostecki et al. 2012; Vinagre et al., 2008b), the global TEF used for this analysis corresponded, for each element ( $\mathrm{N}$ and $\mathrm{C}$ ), to the sum of that from primary producers or POM to benthic invertebrates (YoY preys) and that from invertebrates to YoY soles. A wide range of TEFs values is available for juvenile flatfish in the litterature (Minagawa and Wada, 1984; Bucheister and Latour 2010). However, in the present work, only 2 different global TEFs (Table 3) were compared: one (TEF1) corresponding to the sum of the mean TEF values commonly used in the literature for the primary consumers and the predators (DeNiro \& Epstein, 1978 and 1981; Fry, 2006), and one (TEF2) corresponding to the sum of the mean TEF value commonly used for primary consumers (DeNiro \& Epstein, 1978 and 1981) and a mean TEF value derived from laboratory investigations of TEF variability in the winter flounder Pleuronectes americanus (Bosley et al. 2002), a flatfish with juvenile physiology close to that of sole. These 2 global TEFs were among the most extreme values proposed between primary producers and secondary consumers in the literature, others estimates being generally intermediate (Minagawa and Wada, 1984; Fry, 2006). Therefore, the sensitivity analysis performed probably allowed reliable estimation of the variation in source contributions to be expected given the natural variability of TEFs. For this, the SIAR model was run twice for each site, with the standard error associated to both the global TEF values tested set by default at $0.5 \%$.

\subsection{Calculation of sources' contribution from SIAR mixing model outputs}

For each of the two global TEFs retained, the SIAR mixing model was run on the 13 datasets collected for the 5 nursery sites studied (Table 2) to estimate the ranges in contribution of the four different organic matter sources (FW, SW, MPB, MPh) to YoY sole growth (in \%; see Kostecki et al. (2012) for an example of SIAR model outputs for MSMB). When, for one of these four sources, several isotopic signatures were included in the analysis (i.e. from different rivers or different types of freshwater loadings or for several macrophytes species), 
their contributions were summed to obtain a global contribution range for the corresponding source (FW, SW, MPB or MPh).

To visualize the influence of TEFs variation on the model outputs and provide a first overview of the general patterns in sources contribution among the different sites, a Principal Component Analysis (PCA) was run on the model outputs (26 individuals: 13 samples $\times 2$ runs of the mixing models for the two global TEFs; four variables: the mean estimated contribution of each source being expressed in \%). The differences in source contribution estimates between paired points (i.e. between the two different estimates obtained with the two global TEFs for the same site) were also calculated to provide additional information on the sensitivity of the SIAR mixing model to uncertainty on the TEFs.

\subsection{Intra-site and inter-site variability}

The results from the multiple stations analysed in the Vilaine and the Charente estuaries allowed investigation of the spatio-temporal variations in source (especially freshwater POM) contribution to YoY sole growth within nursery habitats, in link with the position of their site of capture sites with respect to the upstream-downstream salinity gradient and to the interannual variability in river flow (in the Vilaine estuary).

Model outputs were finally compared among the five nursery sites and the differences in sources contribution were analysed in relation to average river flows and the area covered by the intertidal zone in each habitat (Table 1).

\section{Results}

\subsection{Sensitivity of SIAR model outputs to TEFs variations}

The first factorial plan of the PCA performed on the SIAR model outputs (Fig. 2) reflected more than $78 \%$ of the total variability in the dataset and therefore gave a reliable image of the variability in source contribution estimates, both among samples and according to the global TEF retained for the calculations. Source contribution estimates for each sample were generally close for both TEF values, although the seawater POM contributions were systematically lower (of $15 \%$ in average) with TEF2 (Table 4). Differences between samples were higher than that linked to TEF choice, apart for the samples collected in the Vilaine estuary in consecutive years (in 2004 and 2005 and in 2007 and 2008, Fig. 2). Model outputs therefore enabled to confidently identify spatial differences in source contributions, not only between the five nursery sites, but also between different parts of the Vilaine and Charente estuaries.

As contrasts between sites were not obscured by discrepancies linked to TEFs, source contributions for each site were averaged between the two TEFs (TEF1 and TEF2) and the resulting averaged proportions were used to interpret the variations observed among the 13 samples analysed.

\subsection{Intra-habitat variations in food sources for YoY sole}

SIAR model outputs always differed between the upstream and downstream samples from the same nursery habitat (Vilaine or Charente estuaries) and the same year (for the Vilaine estuary), with a consistently higher contribution of seawater POM (SW) in the downstream sampling sites (Fig 2). This systematic change in source contributions along the estuarine 
salinity gradient was confirmed by Fig. 3. For YoY sole located downstream (D; Fig. 1), the contribution of freshwater POM (FW) was lower and compensated by higher contributions of seawater POM and microphytobenthos (MPB). Averaging the contributions of both sampling sites for each year in the Vilaine estuary also showed the existence of inter-annual variations in the contributions of each source to YoY sole growth, with an increase in the contribution of FW and a reduction in that of SW and MPB (Fig. 4a) with increasing river flow (Fig. 4b).

\subsection{Inter-habitat variations in food sources for YoY sole}

The contributions of the four organic matter sources to YoY sole growth differed between the five nursery habitats (Fig. 2 and Fig. 5). Estimated contributions for freshwater POM (FW) varied between $14 \%$ and $35 \%$ according to the nursery site. FW contribution to YOY sole growth was thus substantial everywhere but never dominant. Primary production was the main source of organic matter for young soles irrespective of the nursery habitat: In the Rhone river prodelta, the only non-tidal system, YoY soles' food webs appeared to be mainly supplied by phytoplankton, as indicated by the major contribution of SW (Fig. 5). In the tidal sites however, SW contribution was low and intertidal primary production (by the microphytobenthos and saltmarsh macrophytes) provided the main part $(>50 \%)$ of the organic matter exploited by young soles (Fig. 5). In the MSMB, and the Charente and Vilaine estuaries, macrophytes contribution was low and the microphytobenthos (MPB) was the main source of organic matter sustaining YoY sole growth.

Inter-habitat comparisons of the contributions of the different sources to YoY sole growth revealed an unexpected overall reverse relationship between FW exploitation by young soles and local river flow (Fig. 6). However, this general tendency seemed to be mainly driven by the particularly high river flow observed for the Rhone river prodelta when compared to the four other sectors studied (Table 1). A similar bias was observed when local source contributions were related to intertidal zone area for the five habitats, the general pattern observed for the four tidal sites contrasting with the situation in the Rhone river prodelta (Fig. 7); apart from the Rhone, intertidal production appeared to be the dominant organic matter source for YOY soles.

\section{Discussion}

\subsection{Providing reliable estimates of organic matter source contributions: a difficult challenge}

\subsubsection{Estimates of source contribution at a critical juvenile life stage}

In YoY juveniles of the common sole, muscle isotopic turnover rates (i.e. the speed at which this tissue reaches an new isotopic signature equilibrium after a shift to an isotopically distinct diet) can exceed one month (Vinagre et al., 2008b; Darnaude A.M., personal communication). Therefore, the isotopic signature of some of the sole individuals used for the present meta-analysis $(6-11 \mathrm{~cm}$ in size) might still partly reflect that acquired during their larval life in the marine plankton. Hence, the isotopic signature for older juveniles suggests a much higher exploitation of freshwater POM (Darnaude et al., 2004a; Darnaude, 2005). However, the most important trophic changes in sole occur during the very first months of benthic life (Marchand, 1993), well before the YoY reach the sizes used in the present metaanalysis. Because mortality in the species is maximum during this period and food availability is a major determinant in modulating final population size in sole (Juanes, 2007; Le Pape and 
Bonhommeau, sub), the isotopic signature analysed here reflect that of the sources of organic matter exploited during the critical stage that determines most of the recruitment success in the species.

4.1.2. Accounting for uncertainty on both isotopic signatures and TEFs using mixing models coupled with a sensitivity analysis

In this study, a non-negligible level of uncertainty remains around the correctness of the local isotopic signatures used for the four organic matter sources investigated, especially in the habitats where isotopic signatures were derived from time-series data because measurements concomitant to YoY sole sampling were missing (Table 2). YoY sole isotopic signatures also presented an important variability for a given site and date (Darnaude et al., 2004b; Kostecki et al., 2010; Modéran, 2010; Vinagre et al., 2011; Kostecki et al., 2012). The SIAR software package, based on Bayesian inference and thereby allowing integration in the analysis of both within sources and among samples variabilities (Parnell et al., 2010), was therefore particularly appropriate for this meta-analysis. However, stable isotopes mixing models are highly sensitive to TEFs (Bond and Diamond, 2011). As very different values of TEFs have been previously estimated from prey to consumers (De Niro and Epstein, 1981; Fry, 1999; Post, 2002; McCutchan et al., 2003) and more specifically from preys to juvenile flatfish (Bosley et al., 2002; Bucheister and Latour 2010), the robustness of SIAR outputs to TEF variability had to be tested. Our results demonstrated that SIAR estimates of source contributions were sensitive to variations in the TEF values used for the predictions but the corresponding bias in source contribution estimates was too low to obscure inter-sites variations in source contributions. The only overlap in source contribution estimates with the two extreme TEFs tested concerned samples from the Vilaine estuary collected in the same part of the estuary (upstream or downstream) in couples of years (2004-2005 and 20072008) with similar annual river flow conditions (Fig. 4b). When the same area (upstream or downstream part of the estuary) is sampled for fairly similar annual river flow conditions (2004-2005 and 2007-2008; Fig. 4b); source contribution is also quite similar (Kostecki et al., 2010) and local interannual patterns in source contribution could not be dissociated from differences related to TEFs. Thus, despite the inevitable uncertainty in our estimates linked to the variability in the isotopic signatures (Cloern et al., 2002) dataset used and that linked to inter-site possible variability in TEFs (Post, 2002), the spatio-temporal patterns in source contributions obtained can be considered robust.

\subsubsection{Towards more robust conclusions from a quantitative approach}

SIAR model outputs from the present work supplement the information gathered from the site-specific studies previously conducted in the Rhone river prodelta and in the three estuarine habitats (Tagus, Charente and Vilaine) included in this meta-analysis (Darnaude et al., 2004ab; Kostecki et al., 2010; Modéran, 2010; Vinagre et al., 2011). Hence, the sources of organic matter for young soles and their variations, formerly only identified graphically based on $\delta^{15} \mathrm{~N}$ vs. $\delta^{13} \mathrm{C}$ biplots, were quantified precisely for the first time in these nursery habitats. Our results confirmed the general downstream decrease in freshwater POM exploitation by YoY soles in their estuarine nurseries (Pasquaud et al., 2008; Vinagre et al., 2008b; Kostecki et al., 2010, Kopp et al. sub.) and the positive link between river flow and freshwater POM incorporation at different time scales (Kostecki et al., 2010; Vinagre et al, 2011). However, several previous studies, based on graphic interpretations of stable isotope signatures only, had concluded that YoY soles mainly rely on freshwater organic matter in their estuarine nursery grounds of Western Europe: in front of the Rhone river (Darnaude et al., 2004b) and in the Vilaine estuary (Kostecki et al., 2010) in France; in the Tagus estuary (Vinagre et al., 2008b) in Portugal and in the Thames estuary (Leakey et al., 2008) in the UK. 
Be re-analysing quantitatively the data from 3 of these 4 sites, the present study indicated that freshwater POM contributes to less than a third of the organic matter exploited for growth in YoY sole, at least during the first few months of benthic life investigated here. Despite the sources of uncertainty in our model predictions listed above, graphic misinterpretations of trophic relationships from $\delta^{15} \mathrm{~N}$ vs. $\delta^{13} \mathrm{C}$ biplots (Parnell et al., 2010) might have resulted in previous overestimations of freshwater POM contribution to YoY sole growth. In any case, these discrepancies plead for a more thorough analysis of $\delta^{15} \mathrm{~N}$ vs. $\delta^{13} \mathrm{C}$ biplots and the combined use of quantitative approaches like SIAR mixing models for accurate estimation of source contributions from stable isotopes data.

\subsection{Variations of organic matter sources for YoY soles: from local spatiotemporal patterns in organic matter sources to differences among nursery sectors}

\subsubsection{A systematic moderate influence of freshwater inputs}

As confirmed by the outputs from our models, the organic matter of freshwater origin incorporated into benthic food webs in coastal and estuarine ecosystems is transferred up to juvenile soles (Darnaude, 2003; 2005; Kostecki et al., 2010). It controls both the availability of suitable prey for sole juveniles (Darnaude et al., 2004b) and the size of the latter in their nursery habitats (Le Pape et al., 2003a). Therefore freshwater inputs in organic matter modulate nursery capacity and recruitment success in sole (Le Pape et al., 2003b; Darnaude et al., 2004b). However, although the influence of FW as a trophic source for YoY sole was notable in all the nursery sites tested in the present study and the results for the Charente and the Vilaine estuaries confirmed that its exploitation in sole increases with its availability over an upstream-downstream gradient and with the river flow (Darnaude et al., 2004a; Kostecki et al., 2010), the contribution of this organic matter source to YoY sole growth appeared to remain quite low irrespective of the nursery site. The highest contribution (35\%) was surprisingly found in the MSMB, where freshwater inputs are very limited (Cugier et al., 2010). The widespread hypotheses of a larger exploitation of freshwater inputs by sole juveniles in large estuaries and of a marked difference between the organic matter sources sustaining their growth in their estuarine and in their marine nursery sites (Kostecki et al., 2012) were therefore not confirmed by the present meta-analysis. This can partly result from the size classes of YOY sole selected for inclusion in the analysis, especially since isotopic signatures in older YoY sole (collected in late autumn) reflected a more pronounced freshwater influence in front of the Rhone river (Darnaude 2003). However, YoY sole behaviour also contribute to the lack of inter-site contrast evidenced here. Hence, the common sole is not considered a strictly estuarine dependent species (Araujo et al., 2000; Le Pape et al., 2003b). Its juveniles do not use the most oligohaline parts of the estuaries (Rochette et al., 2010) and, although YoY spatial distribution changes during development (Dorel et al., 1991), their salinity niche during their first months of benthic life is quite similar among nursery sectors (Le Pape et al., 2003b; Rochette et al., 2010) and their distribution drifts downstream with increasing river flow (Le Pape et al., 2003a). This suggests that YoY face a similar range of freshwater influence irrespective of the river discharge in estuarine habitats. It is therefore not particularly surprising that the contribution of FW to their growth is not more important in larger estuaries. YoY sole behaviour also explains the surprising high FW contribution to sole growth found in the marine MSMB. In this bay, sole juveniles concentrate in front of small tributaries (Kostecki et al., 2012), in restricted areas under noticeable estuarine influence (Cugier et al., 2010). Low salinity has been shown to facilitate metamorphosis in the species and attract its larvae (Koutsikopoulos et al., 1989), which use selective tidal stream transport to reach appropriate nursery habitats (Boehlert and Mundy, 1988; Amara et al., 1998; Grioche et al., 2000; Ramzi et al., 2001). Attraction by sediment or food chemical signatures was also suggested as an explanation for this estuarine tropism, although the nature of the cues for their detection remains unclear (Amara et al., 1998; 
Vinagre et al. 2007). Anyhow, the resulting distribution of YoY sole in the MSMB explains the relatively high freshwater POM contribution to their growth in this marine zone despite low freshwater inputs and reinforce the hypothesis of YoY sole being attracted toward areas under freshwater influence, where their growth is enhanced (Le Pape et al., 2003c).

\subsubsection{A significant influence of intertidal production}

This meta-analysis revealed the major role of benthic intertidal primary production in sustaining YoY food webs and maintaining the nursery function of estuarine and coastal tidal ecosystems. For the four tidal habitats studied, the contribution of intertidal benthic production to YoY sole growth was shown to exceed $50 \%$, in accordance with results on the main organic food sources sustaining fish production in tropical estuaries (Melville and Connolly, 2003). In temperate estuaries, the production of various species of commercial interest had been suggested to be predominantly sustained by saltmarsh macrophytes detritus, either through direct ingestion or via their incorporation in local benthic food webs (Boesch and Turner, 1984). This is nuanced by the results from the present analysis, which confirmed the contribution of organic matter from saltmarsh plants to fish production, notably in the MSMB (Lafaille et al., 1998), but stressed the prime role of the microphytobenthos in sustaining juvenile marine fish growth in tidal areas, as already suggested in the Tagus estuary (França et al., 2012) and the MSMB (Kostecki et al., 2012). Our results suggest however that the contribution of benthic primary production to YoY sole growth could be very low in non-tidal nursery habitats. Indeed, in the Rhone river prodelta, the contribution of autochtonous phytoplankton prevails because water turbidity, linked to the presence of a particularly dense river plume, limits benthic primary production (Bodoy and Plante-Cuny, 1980). Supplementary analyses that include other types of Mediterranean nursery habitats (coastal lagoons, estuaries, sheltered bays) are needed to confirm this observation and further investigate organic matter sources for YoY sole in non-tidal systems.

Our conclusions echo previous calls for the preservation and even the restoration of the quality of intertidal zones in tidal areas (Elliott et al., 2007). Indeed, our results stress that juvenile growth in the common sole depend highly on intertidal food sources, as in other coastal and estuarine dependent species (França et al., 2012; Kostecki et al., 2012). Maintaining the productivity of habitats that sustain nursery function should be the primary focus for such fish species, whose population size depends on trophic resources at the juvenile stage (Lamberth et al., 2009; van de Wolfshaar et al. 2011; Le Pape and Bonhommeau, sub.). Nevertheless, primary production in estuarine and coastal habitats is highly dependent on freshwater loadings in inorganic nutrients (Mallin et al., 1993). Because the latter enhance both micro- (Underwood and Provot, 2000) and macro-phytobenthic productions (Valiela and Teal, 1974) in the intertidal zone, the maintenance of river inputs to the coastal zone is also of primary importance for flatfish stock maintenance. Our results confirm that future modifications of river inputs to the coastal zone in Western Europe, under the combined influence of climate change and anthropogenic freshwater use, could alter profoundly the nursery function of estuarine and coastal ecosystems (Dolbeth et al., 2008). At least in the common sole, the consequences on fisheries production of such changes could prove dramatic if both the direct (through benthos use of freshwater POM) and indirect (through nutrients use by local primary producers) enrichments of YoY food webs by riverine inputs were altered. Appropriate measures will have to be urgently taken to preserve the nursery function and capacity of costal and estuarine systems and, as a consequence, the exploited stocks and related fisheries. 


\section{Acknowledgements}

This project used data from the French Coastal Monitoring Network SOMLIT (Service d'Observation en Milieu LITtoral; http://somlit.epoc.u-bordeaux1.fr/fr/; P.I. Benoit Sautour, UMR EPOC, OASU, Arcachon, France). We thank the SOMLIT teams of Roscoff (P.I. Pascal Morin) and Marseille (P.I. Patrick Raimbaut) for providing us with their data. Other data were obtained in the scope of projects conducted in Portuguese estuaries, funded by Fundação para a Ciência e para a Tecnologia and on French coastal and estuarine sectors, funded by the French national program for coastal environment (PNEC). We thank Caroline Nérot for her contribution to data providing. Julien Moderan and Caroline Kostecki were funded by a $\mathrm{PhD}$ grant from the French ministry of research. Catarina Vinagre acknowledges the grant SFRH/BPD/34934/2007 and Susana França the grant SFRH/BD/27627/2006 from the Portuguese National Science Foundation (FCT). We are grateful to Sophie Pasquier for compiling references and to Rowena Stern (SAHFOS, Plymouth, UK) and Zara Reveley (Universidade de Lisboa, Portugal) for suggesting English improvements. They would like to apologize to colleagues from various research institutes (Valérie David, Valérie Ménage, Benoit Sautour) for removing some other study sectors from the analysis after their data collection because of the lack of standardized data. We also would like to thank to the two anonymous reviewers for their helpful advice and significant improvements of the manuscript.

\section{References}

Amara, R., Poulard, J.C., Lagardere, F., Desaunay, Y., 1998. Comparison between the life cycle of two Soleidae, the common sole, Solea solea, and the thickback sole, Microchirus variegatus, in the Bay of Biscay (France). Environmental Biology of Fishes 53, 193-209.

Araujo, F.G., Williams, W.P., Bailey, R.G., 2000. Fish assemblages as indicators of water quality in the middle Thames estuary, England (1980-1989). Estuaries 23, 305-317.Arbach Leloup F., Desroy N., Le Mao P., Pauly D., Le Pape O., 2008. Interactions between a natural food web, shellfish farming and exotic species: the case of the Bay of Mont Saint Michel (France). Estuarine, coastal and shelf science 76, 111-120.

Auger P.A., Diaz F., Ulses C., Estournel C., Neveux J., Joux F., Pujo-Pay M., Naudin J.J., 2010. Functioning of the planktonic ecosystem of the Rhone river plume (NW Mediterranean) during spring and its impact on the carbon export: a field data and 3-D modelling combined approach. Biogeosciences 7, 9039-9116

Banaru, D., Harmelin-Vivien, M., 2009. Feeding behaviour of Black Sea bottom fishes: did it change over time? Acta Oecologia 35, 769-777.

Beck, M.W., Heck, K.L., Able, K.W., Childers, D.L., Eggleston, D.B., Gillanders, B.M., Halpern, B., Hays, C.G., Hostino, K., Minello, T.J., Orth, R.J., Sheridan, P., Weinstein, M.P., 2001. The role of nearshore ecosystems as fish and shellfish nurseries. BioScience 51, 633641.

Bodoy, A., Plante-Cuny, M.-R.,1980. Evaluation simultanée des biomasses et productions primaires phytoplanctonique et microphytobenthique en milieu côtier. Comptes Rendus de l'Académie des Sciences, Paris, 290, 667-670.

Boehlert, G.W., Mundy, B.C., 1988. Roles of behavioral factors in larval and juvenile fish recruitment to estuarine nursery areas. American Fisheries Society Symposium 3, 51-67.

Boesch D.F., Turner D.F., 1984. Dependence of fishery species on salt marshes: The role of food and refuge. Estuaries and Coasts 7(4), 460-468.

Bond, A., Diamond, A., 2011. Recent bayesian-isotope mixing models are highly sensitive to variation in discrimination factors. Ecological applications 21:1017-23.

Bosley, K.L., Witting, D.A., Chambers, R.C., Wainright, S.C., 2002. Estimating turnover rates of carbon and nitrogen in recently metamorphosed winter flounder Pseudopleuronectes americanus with stable isotopes. Marine Ecology Progress Series 236: 233-240. 
Bucheister A., Latour R.J., 2010. Turnover and fractionation of carbon and nitrogen stable isotopes in tissues of a migratory coastal predator, summer flounder (Paralichthys dentatus). Canadian Journal of Fisheries and Aquatic Sciences 67: 445-461.

Cloern, J.E., Canuel, E.A., Harris, D., 2002. Stable carbon and nitrogen isotope composition of aquatic and terrestrial plants of the San Francisco Bay estuarine system. Limnology and Oceanography 47, 713-729.

Cugier, P., Struski, C., Blanchard, M., Mazurié, J., Pouvreau, S., Olivier, F., Trigui, J.R., Thiébaut, E., 2010. Assessing the role of benthic filter-feeders on phytoplanktonic production in a shellfish farming site: Mont Saint Michel Bay, France. Journal of Marine Systems 82, 2134.

Darnaude, A.M., 2003. Apports fluviaux en zone côtière et réseaux trophiques marins benthiques : transfert de matière organique particulaire terrigène jusqu'aux poissons plats au large du Rhône. PhD, Univ. Aix-Marseille II, 372 pp.

Darnaude, A., 2005. Fish ecology and terrestrial carbon use in coastal areas: implications for marine fish production. Journal of Animal Ecology 74, 864-876.

Darnaude, A.M., Harmelin-Vivien, M.L., Salen-Picard, C., 2001. Food partitionning among flatfih (Pisces: Pleuronectiforms) juveniles in a mediterranean coastal shallow sandy area. Journal of Marine Biological Association of the United Kingdom 81, 119-127.

Darnaude, A.M., Salen-Picard, C., Harmelin-Vivien, M.L., 2004a. Depth variation in continental particulate organic matter use by marine coastal benthic communities off the Rhone river (NW Mediterranean). Marine Ecology Progress Series, 275: 47-57.

Darnaude, A.M., Salen-Picard, C., Polunin, N., Harmelin-Vivien, M.L., 2004b. Trophodynamic linkage between river runoff and coastal fishery yield elucidated by stable isotope data in the Gulf of Lions (NW Mediterranean). Oecologia 138, 325-332.

DeNiro, M.J., Epstein, S., 1978. Influence of diet on the distribution of carbon isotopes in animals. Geochimica et Cosmochimica Acta 42, 495-506.

DeNiro, M.J., Epstein, S., 1981. Influence of diet on the distribution of nitrogen isotopes in animals. Geochimica et Cosmochimica Acta 45, 341-351.

Dolbeth, M, Martinho, F, Viegas, I, Cabral, H, Pardal, M.A., 2008. Estuarine production of resident and nursery fish species: conditioning by drought events. Estuarine, Coastal and Shelf Science 78, 51-60.

Dorel, D., Koutsikopoulos, C., Desaunay, Y., Marchand, J., 1991. Seasonal distribution of young sole (Solea solea (L.)) in the nursery ground of the Bay of Vilaine (Northern Bay of Biscay). Netherlands Journal of Sea Research 27, 297-306.

Elliott, M., Burdon, D., Hemingway, K. L., Apitz, S. E., 2007. Estuarine, coastal and marine ecosystem restoration: Confusing management and science - A revision of concept. Estuarine coastal and shelf science 74(3), 349-366.

França, S., Vasconcelos, R.P., Tanner, S.E., Máguas, C., Costa, M.J., Cabral, H.N., 2012. Assessing food web dynamics and relative importance of organic matter sources for fish species in two Portuguese estuaries: a stable isotope approach,Marine Environmental Research 72(4), 204-215.

Fry, B., 1999. Using stable isotopes to monitor watershed influence on aquatic trophodynamics. Canadian journal of fisheries and aquatic sciences 56, 2167-2171.

Fry, B., 2006. Stable isotope ecology. Springer, New York, USA, 308pp.

Gibson, R.N., 1994. Impact of habitat quality and quantity on the recruitment of juvenile flatfishes. Netherlands Journal of Sea Research 32, 191-206.

Grioche, A., Harlay, X., Koubbi, P., Fraga Lago, L., 2000. Vertical migrations of fish larvae: Eulerian and Lagragian observations in the Eastern English Channel. Journal of Plankton Research 22, 1813-1828.

Iles, T.C., Beverton, J.H., 2000. The concentration hypothesis: the statistical evidence. ICES Journal of Marine Science 57, 216-227.

Juanes, F., 2007. Role of habitat in mediating mortality during the post-settlement transition phase of temperate marine fishes. Journal of Fish Biology 70, 661-677.

Kopp, D., H. Le Bris, L. Grimaud, C. Nérot, Brind'Amour, A. Submitted. Spatial analysis of the trophic interactions between bentho-demersal fish species and their potential preys along a 
coastal-estuarine gradient using stable isotopes and gut contents. Canadian Journal of Fisheries and Aquatic Science.

Kostecki, C., Le Loc'h, F., Roussel, J.M., Desroy, N., Huteau, D., Riera, P., Le Bris, H., Le Pape, O., 2010. Dynamics of an estuarine nursery ground: the spatiotemporal relationship between the river flow and the food web of the juvenile common sole (Solea solea) as revealed by stable isotopes analysis. Journal of Sea Research 64, 54-60.

Kostecki, C., Roussel, J.M., Desroy, N., Roussel, G., Lanshere, J., Le Bris, H., Le Pape, O., 2012. Trophic ecology of juvenile flatfish in a coastal nursery ground: contributions of intertidal primary production and freshwater particulate organic matter. Marine Ecology Progress Series 449, 221-232.

Koutsikopoulos, C., Desaunay, Y., Dorel, D., Marchand, J., 1989. The role of coastal areas in the life history of sole (Solea solea L.) in the Bay of Biscay. Scientia Marina 53, 567-575.

Koutsikopoulos, C., Fortier, L., Gagne, J.A., 1991. Cross-well dispersion of dover sole (Solea solea (L.)) eggs and larvae in Biscay Bay and recruitment to inshore nurseries. Journal of Plankton Research 13, 923-945.

Koutsikopoulos, C., Lacroix, N., 1992. Distribution and abundance of sole (Solea solea L.) eggs and larvae in the Bay of Biscay between 1986 and 1989. Netherlands Journal of Sea. Research 29, 81-91.

Laffaille, P., Brosse, S., Feunteun, E., Baisez , A., Lefeuvre, J.C., 1998. Role of fish communities in particulate organic matter fluxes between salt marshes and coastal marine waters in the Mont Saint-Michel Bay. Hydrobiologia 373-374, 121-133.

Lamberth, S., Drapeau, L., Branch, G.M., 2009. The effects of altered freshwater inflows on catch rates of non estuarine dependent fish in multispecies nearshore fsheries. Estuarine, Coastal and Shelf Science 84, 527-538.

Le Pape, O., Bonhommeau, S., (submitted). Density dependence and trophic limitation of marine fish in coastal and estuarine nursery grounds: the food limitation hypothesis. Fish and Fisheries.

Le Pape, O., Chauvet, F., Desaunay, Y., Guerault, D., 2003a. Relationship between interannual variations of the river plume and the extent of nursery grounds for the common sole (Solea solea, L.) in Vilaine Bay. Effects on recruitment variability. Journal of Sea Research 50, 177-185.

Le Pape, O., Chauvet, F., Mahevas, S., Lazure, P., Guerault, D., Desaunay, Y., 2003b. Quantitative description of habitat suitability for the juvenile common sole (Solea solea, L.) in the Bay of Biscay (France) and the contribution of different habitats to the adult population. Journal of Sea Research 50 139-149.

Le Pape, O., Holley, J., Guerault, D., Desaunay, Y., 2003c. Quality of coastal and estuarine fish habitats: estimations based on the size of juvenile common sole (Solea solea L.). Estuarine, Coastal and Shelf Science 58 793-803.

Leakey, C.D.B., Atrill, M.A., Jennings, S., Fitzsimons, M.F., 2008. Stable isotopes in juvenile marine fishes and their invertebrate prey from the Thames estuary, UK, and adjacent coastal regions. Estuarine, Coastal and Shelf Science 77, 513-522.

Leguerrier D., Niquil N., Boileau N., Rzeznik J., Sauriau P.G., Le Moine O., Bacher C., 2003. Numerical analysis of the food web of an intertidal mudflat ecosystem on the Atlantic coast of France. Marine Ecology Progress Series 246, 17-37.

Mallin, M.A., Paerl, H.W., Rudek, J., Bates P.W., 1993. Regulation of estuarine primary production by watershed rainfall and river flow. Marine Ecology Progress Series. 93: 199203.

Marchand, J., 1993. The influence of seasonal salinity and turbidity maximum variations on the nursery function of the Loire estuary (France). Netherlands Journal of Aquatic Ecology 27, 427-436.

McCutchan, J.H., Lewis, W.M., Kendall, C., McGrath, C.C., 2003. Variation in trophic shift for stable isotope ratios of carbon, nitrogen, and sulfur. Oikos 102:378-390.

Melville, A.J., Connolly, R.M., 2003. Spatial analysis of stable isotope data to determine primary sources of nutrition for fish. Oecologia 136, 499-507. 
Millner, R.S., Whiting, C.L., 1990. Distribution and abundance of juvenile sole and plaice in the eastern english Channel from young fish surveys. ICES, CM 1990/G38

Minagawa, M., Wada, E., 1984. Stepwise enrichment of $15 \mathrm{~N}$ along food chains: further evidence and the relation between $\mathrm{d} 15 \mathrm{~N}$ and animal age. Geochimica et Cosmochimica Acta $48,1135-1140$.

Modéran, J., 2010. Estuaire de la Charente: structure de communautés et écologie trophique du zooplancton, approche ecosystémique de la contamination métallique. $\mathrm{PhD}$ thesis, Université de La Rochelle, France: 236pp.

Modéran, J., David, V., Bouvais, P., Richard, P., Fichet, D., 2012. Organic matter exploitation in a highly turbid environment: planktonic food web in the Charente estuary, France. Estuarine, Coastal and Shelf Science 98, 126-137.

Nérot, C., 2011. Invertébrés benthiques et biomarqueurs : témoins du fonctionnement trophique des écosystèmes côtiers. PhD thesis, Université de Bretagne Occidentale, France : 152pp.

Nicolas, D., Lobry, J., Lepage, M., Sautour, B., Le Pape, O., Cabral, H., Uriarte, A., Boët, P., 2010. Fish under influence: a macroecological analysis of relations between fish species richness and environmental gradients among European tidal estuaries. Estuarine, Coastal and Shelf Science 86: 137-147.

Parnell, A.C., Inger, R., Bearhop, S., Jackson, A.L., 2010. Source partitionaing using stable isotopes: coping with too much variation. PLoS ONE 5, e9672.

Pasquaud, S., Elie, P., Jeantet, C., Billy, I., Martinez, P., Girardin, M., 2008. A preliminary investigation of the fish food web in the Gironde estuary, France, using dietary and stable isotope analyses. Estuarine Coastal and Shelf Science 78, 267-279.

Peterson, B.J., Fry, B., 1987. Stable isotopes in ecosystem studies. Annual Reviews of Ecology Evolution and Systematics 18, 293-320.

Peterson, M., 2003. A conceptual view of environment-habitat-production linkages in tidal river estuaries. Reviews in Fisheries science 11, 291-313.

Post, D.M., 2002. Using stable isotopes to estimate trophic position: models, methods, and assumptions. Ecology, 83, 703-718.

R Development Core Team (2009). R: A language and environment for statistical computing. $\mathrm{R}$ Foundation for Statistical Computing, Vienna, Austria. ISBN 3-900051-07-0, URL http://www.R-project.org.

Ramzi, A., Arino, O., Koutsikopoulos, C., Boussouar, A., Lazure, P., 2001. Modelling and numerical simulations of larval migration of the sole (Solea solea (L.)) of the Bay of Biscay. Part 2: numerical simulations. Oceanologica acta 24, 113-124.

Riera, P., 1995. Origine et devenir de la matière organique dans un écosystème estuarien à vocation conchylicole. Application du traçage isotopique naturel. PhD Thesis- Université de Bordeaux I, France: 214 pp.

Rijnsdorp, A.D., Van, B.F.A., Flatman, S., Millner, R.M., Riley, J.D., Giret, M., De Clerck, R., 1992. Recruitment of sole stocks, Solea solea (L.), in the northeast Atlantic. Netherlands Journal of Sea Research 29, 173-192.

Riou, P., Le Pape, O., Rogers, S.I., 2001. Relative contributions of different sole and plaice nurseries to the adult population in the Eastern Channel: application of a combined method using generalized linear models and a geographic information system. Aquatic Living Resources 14 125-135.

Rochette, S., Huret, M., Rivot, E., Le Pape, O., 2012. Coupling hydrodynamic and individualbased models to simulate long-term larval supply on coastal nursery area. Fisheries and oceanography doi:10.1111/j.1365-2419.2012.00621.x

Rochette, S., Rivot, E., Morin, J., Mackinson, S., Riou, P., Le Pape, O., 2010. Effect of nursery habitat degradation on flatfish population: Application to Solea solea in the Eastern Channel (Western Europe). Journal of Sea Research 64, 34-44.

Savina, M., Lacroix, G., Ruddick, K., 2009. Modelling transport of common sole larvae in the Southern North Sea: Influence of hydrodynamics and larval vertical movements. Journal of Marine Systems 81 (1-2), 86-98. 
Underwood, G.J.C., Provot, L. 2000. Determining the environmental preferences of four estuarine epipelic diatom taxa: growth across a range of salinity, nitrate and ammonium conditions European. Journal of Phycology, 35(2): 173-182.

Valiela, I., Teal, J.M., 1974. Nutrient Limitation in Salt Marsh Vegetation. Ecology of Halophytes, Reimold, R. J., Queen, W. H. (Eds.). Academic Press, Inc., New York, pp. 547563.

Van der Veer, H.W., Berghahn, R., Miller, J.M., Rijnsdorp A.D., 2000. Recruitment in flatfish, with special emphasis on North Atlantic species: Progress made by the flatfish symposia. ICES Journal of Marine Science 57, 202-215.Van de Wolfshaar, K., HilleRisLambers, R., Gardmark, A., 2011. Effect of habitat productivity and exploitation on populations with complex life cycles. Marine Ecology Progress Series 438,175-84.

Vander Zanden, M.J., Rasmussen, J.B., 2001. Variation in $\delta 15 \mathrm{~N}$ and $\delta 13 \mathrm{C}$ trophic fractionation: implications for aquatic food web studies. Limnology and Oceanography 46, 2061-2066.

Vinagre, C., Costa, M.J., Cabral, H.N., 2007. Impact of climate and hydrodynamics on sole larval immigration towards the Tagus estuary, Portugal. Estuarine, Coastal and Shelf Science 75, 516-524.

Vinagre C., Cabral H., 2008. Prey consumption by juvenile soles, Solea solea and Solea senegalensis, in the Tagus estuary, Portugal. Estuarine, Coastal and Shelf Science 78, 4550 .

Vinagre, C., Amara, R., Maia, A., Cabral, H.N. 2008a. Latitudinal variation in spawning season and growth of 0-group sole, Solea solea (L.). Estuarine, Coastal and Shelf, Science 78, 521-528.

Vinagre, C., Salgado, J., Costa, M., Cabral, H., 2008b. Nursery fidelity, food web interactions and primary sources of nutrition of the juveniles of Solea solea and S. Senegalensis in the Tagus estuary (Portugal): a stable isotope approach. Estuarine, Coastal and Shelf Science 76, 255-264.

Vinagre, C., Salgado, J., Cabral, H.N., Costa M.J., 2011. Food Web Structure and Habitat Connectivity in Fish Estuarine Nurseries-Impact of River Flow. Estuaries and coasts 34, 663-674.

Yokoyama, H., Ishihi, Y., 2008. Variation in food sources of the macrobenthos along a landsea transect: a stable isotope study. Marine Ecology Progress Series 346, 127-141.

Wheeler,A., 1978. Key to the fishes of Northern Europe. F. Warne ed., London :380 pp.

Woodland, R., Secor, D., Fabrizio, M., Wilberg, M., 2012. Comparing the nursery role of inner continental shelf and estuarine habitats for temperate marine fishes. Estuarine, Coastal and Shelf Science 99(1):61-73.

Zetsche, E., Thornton, B., Midwood, A., Witte, U., 2011. Utilisation of different carbon sources in a shallow estuary identified through stable isotope techniques. Continental Shelf Research 31, 832-840. 


\section{Tables}

Table 1: Average annual river flow and percentage of intertidal area for the five estuarine systems considered in this study (Nicolas et al., 2010).

\begin{tabular}{|c|c|c|}
\hline Estuaries & $\begin{array}{c}\text { Average annual river flow } \\
\left(\mathrm{m}^{3} \cdot \mathrm{s}^{-1}\right)\end{array}$ & $\begin{array}{c}\text { Proportion of intertidal area } \\
(\%)\end{array}$ \\
\hline Mont St Michel Bay & 27 & {$[60,80[$} \\
\hline Vilaine & 73 & {$[20,40[$} \\
\hline Charente & 40 & {$[40,60[$} \\
\hline Rhône & 1700 & {$[0,20[$} \\
\hline Tagus & 300 & {$[40,60[$} \\
\hline
\end{tabular}


Table 2: Standardized stable isotopes data collected for the meta-analysis.

"FW, Freshwater POM, SW, Seawater POM, MPB, microphytobenthos, MPh, Macrophytes, Up, upstream, Dw, downstream of the estuary. Surv: sources are sampled in the same survey period as YoY and data come from the same reference, TS: sources are taken from time series indicated in reference, period (Month Year) and sample stations are indicated, No: the source was not considered as significant.

\begin{tabular}{|c|c|c|c|c|c|c|c|c|c|}
\hline \multirow{2}{*}{$\begin{array}{l}\text { Nursery } \\
\text { areas }\end{array}$} & & \multicolumn{3}{|c|}{ Young of the Year sole (YoY) } & \multicolumn{4}{|c|}{ Sources } & \multirow[t]{2}{*}{ References } \\
\hline & $\begin{array}{l}\text { Intrasite } \\
\text { sample }\end{array}$ & Date & Number & $\begin{array}{l}\text { Mean size } \\
(\mathrm{mm})\end{array}$ & $\mathrm{FW}^{*}$ & $\mathrm{SW}^{*}$ & $\mathrm{MPB}^{*}$ & $\mathrm{MPh}^{*}$ & \\
\hline $\begin{array}{l}\text { Mont St } \\
\text { Michel }\end{array}$ & & Aug. 08 & 51 & 78 & Surv $^{*}$ & $\mathrm{TS}^{*}$ & Surv & Surv & $\begin{array}{c}\text { Kostecki et al. (2012) } \\
\text { TS: Somlit, station "Astan", Jun-Sep } 2009\end{array}$ \\
\hline \multirow{8}{*}{ Vilaine } & $\mathrm{Up}^{*}$ & \multirow{2}{*}{ July 04} & 5 & 80 & \multirow{8}{*}{ Surv } & \multirow{8}{*}{ Surv } & \multirow{8}{*}{ Surv } & \multirow{8}{*}{ Surv } & \multirow{8}{*}{$\begin{array}{c}\text { Kostecki et al. (2010), } \\
\text { excepted for SW: } \\
\text { Néro (2011), station "Est Hoedic" }\end{array}$} \\
\hline & $\mathrm{Dw}^{*}$ & & 5 & 65 & & & & & \\
\hline & $\mathrm{Up}$ & Julv 05 & 5 & 82 & & & & & \\
\hline & Dw & July os & 5 & 95 & & & & & \\
\hline & $\mathrm{Up}$ & \multirow{2}{*}{ July 07} & 5 & 76 & & & & & \\
\hline & Dw & & 17 & 68 & & & & & \\
\hline & Up & \multirow{2}{*}{ July 08} & 24 & 74 & & & & & \\
\hline & Dw & & 5 & 69 & & & & & \\
\hline \multirow{2}{*}{ Charente } & Up & \multirow{2}{*}{ Sept. 07} & 17 & 97 & \multirow{2}{*}{ Surv } & \multirow{2}{*}{$\mathrm{TS}$} & \multirow{2}{*}{ Surv } & \multirow{2}{*}{$\mathrm{No}^{*}$} & \multirow{2}{*}{$\begin{array}{l}\text { Surv: Modéran (2010); Modéran et al. (2012) } \\
\text { TS: Riera (1995), station "Ré", May-Sep } 1998\end{array}$} \\
\hline & Dw & & 7 & 94 & & & & & \\
\hline Rhône & & June 01 & 13 & 79 & Surv & $\mathrm{TS}$ & No & Surv & $\begin{array}{c}\text { Surv: Darnaude et al. (2004) } \\
\text { TS: Somlit, station “Frioul”, Mar- Jun } 2010\end{array}$ \\
\hline Tagus & & July 09 & 6 & 83 & $\mathrm{TS}$ & Surv & Surv & Surv & $\begin{array}{c}\text { Vinagre et al. (2011b) } \\
\text { TS: Vinagre et al. (2008b), May-Sept } 2001\end{array}$ \\
\hline
\end{tabular}


Table 3: Trophic enrichment factors (TEF) from sources to YoY

\begin{tabular}{|c|c|c|c|c|}
\hline Element & Set of TEF & Source-Prey & Prey-YoY & $\Sigma$ Source-Yoy \\
\hline \multirow{2}{*}{$\delta{ }^{\square 13} \mathrm{C}$} & TEF1 & \multirow{2}{*}{1} & 1 & 2 \\
\cline { 2 - 3 } & TEF2 & & 2 & 3 \\
\hline \multirow{2}{*}{$\delta{ }^{15} \mathrm{~N}$} & TEF1 & \multirow{2}{*}{2.2} & 3.4 & 5.6 \\
\cline { 2 - 3 } \cline { 4 - 5 } & TEF2 & \multirow{2}{*}{2.0 .3} & 1.9 \\
\hline
\end{tabular}

Table 4: Differences in source contributions for YoY (in \%) between estimates realized with the two tested enrichment factors, calculated on the 13 samples

\begin{tabular}{|c|c|c|c|c|c|c|}
\hline & \multicolumn{2}{|c|}{ SW } & \multicolumn{2}{c|}{ FW } & \multicolumn{2}{c|}{ Intertidal: MPB+Mph } \\
\hline & mean & $\sigma$ & mean & $\sigma$ & mean & $\sigma$ \\
\hline & & & & & & \\
\hline TEF1 & 37.3 & 19.1 & 14.4 & 12.4 & 48.2 & 15.1 \\
\hline TEF2 & 22.7 & 16.7 & 22.1 & 11.8 & 55.2 & 18.6 \\
\hline TEF2-TEF1 & & & & & & \\
\hline
\end{tabular}


Fig. 1. Location of the five study sites along the North East Atlantic coast considered in this study. In the two upper panels, the upstream (U) and downstream (D) locations of juvenile sole data collection in the Vilaine and Charente estuaries are presented.

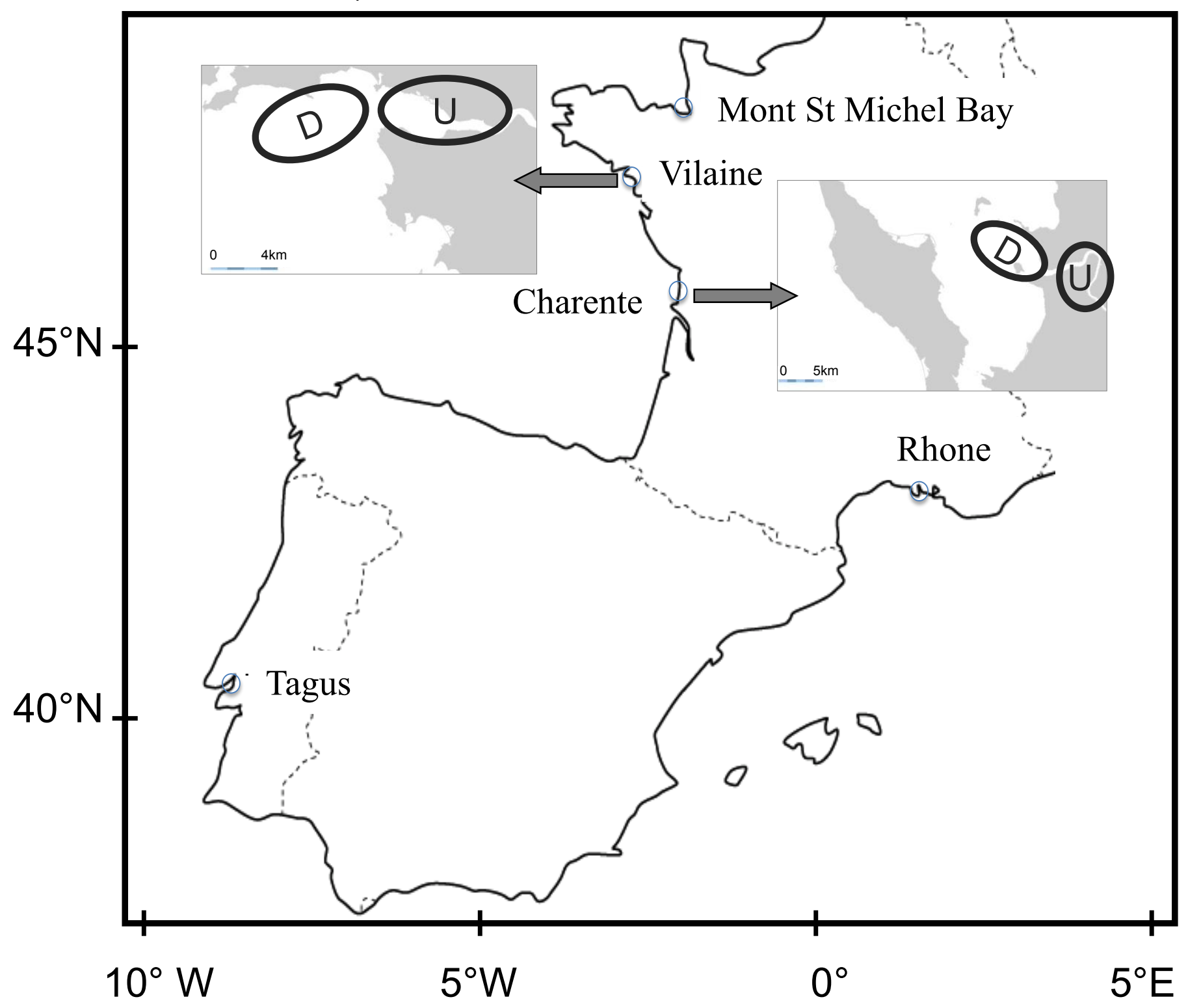


Individuals factor map (PCA)

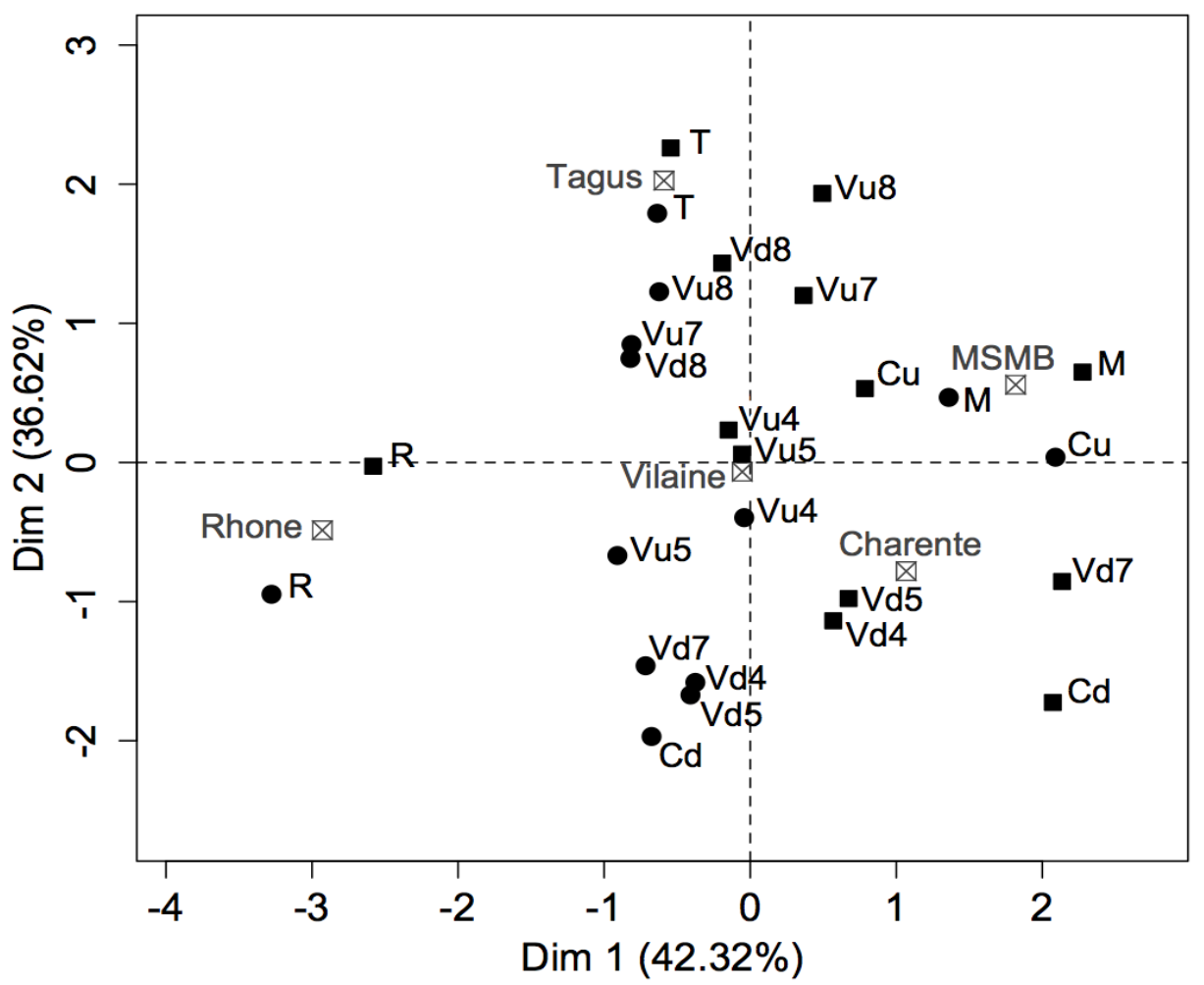

b

Variables factor map (PCA)

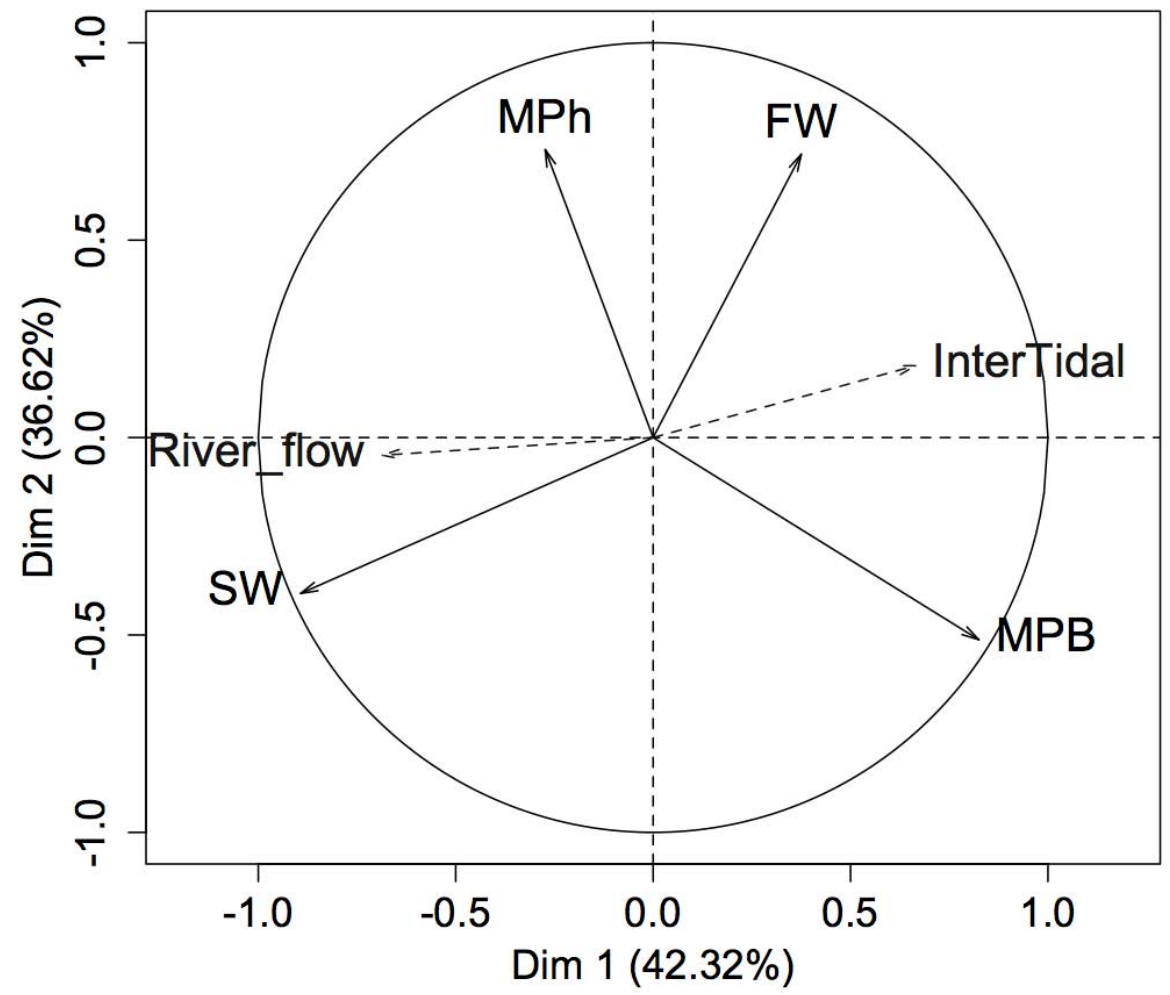

Fig. 2. First factorial plan of a Principal Component Analysis on the contributions (in \%) of the 4 organic matter sources in YoY, calculated on the 13 samples collected on the five nursery sectors (Table 2) with 2 different TEFs (Table 3 ). a) 26 individuals (13 samples * 2 TEFs) with their character code (First, cap. letter for the nursery sector, "M" MSMB, "V" Vilaine, "C" Charente, "R" Rhone and "T" Tagus; second, when needed, min. letter for spatial subsamples "u" for upstream and "d" for downstream; third, Vilaine only, number for the sampling year in 2000s). Symbols depend on the TEF, filled circle for TEF1 and filled squares for TEF2. Sector barycentre is indicated as crossed squares. b) Variables (4 sources), dashed lines indicating the projection of supplementary variables, not included in the analysis. 

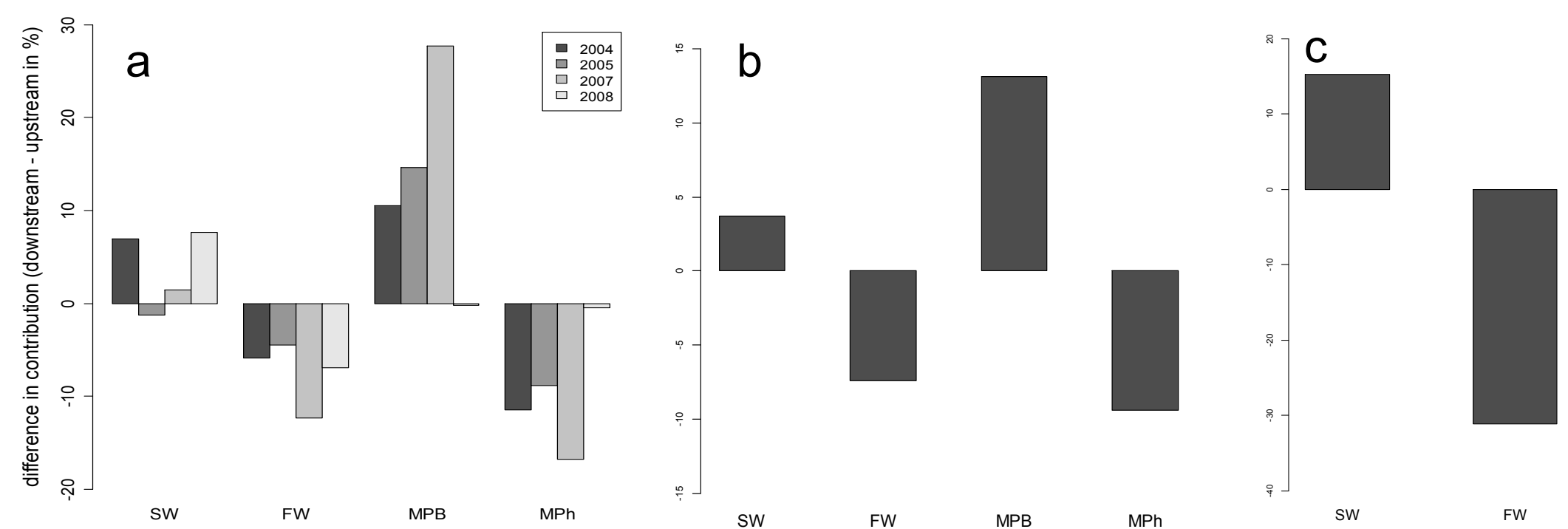

sW

MPh

SW

FW

MPB

Fig. 3. Differences in organic matter sources contribution (in \%) for YoY between the outer and the inner parts of the estuaries a) for the 4 studied years in the Vilaine, b) in average among years in the Vilaine, c) in the Charente. 
Fig. 4. a) Sources' contribution in the Vilaine estuary with relation to the river flow on the 4 studied years a) contributions (in \%) of the 4 sources, b) mean river flow $\left(\mathrm{m}^{3} \cdot \mathrm{s}^{-1}\right)$ before and during YoY settlement, from February to June
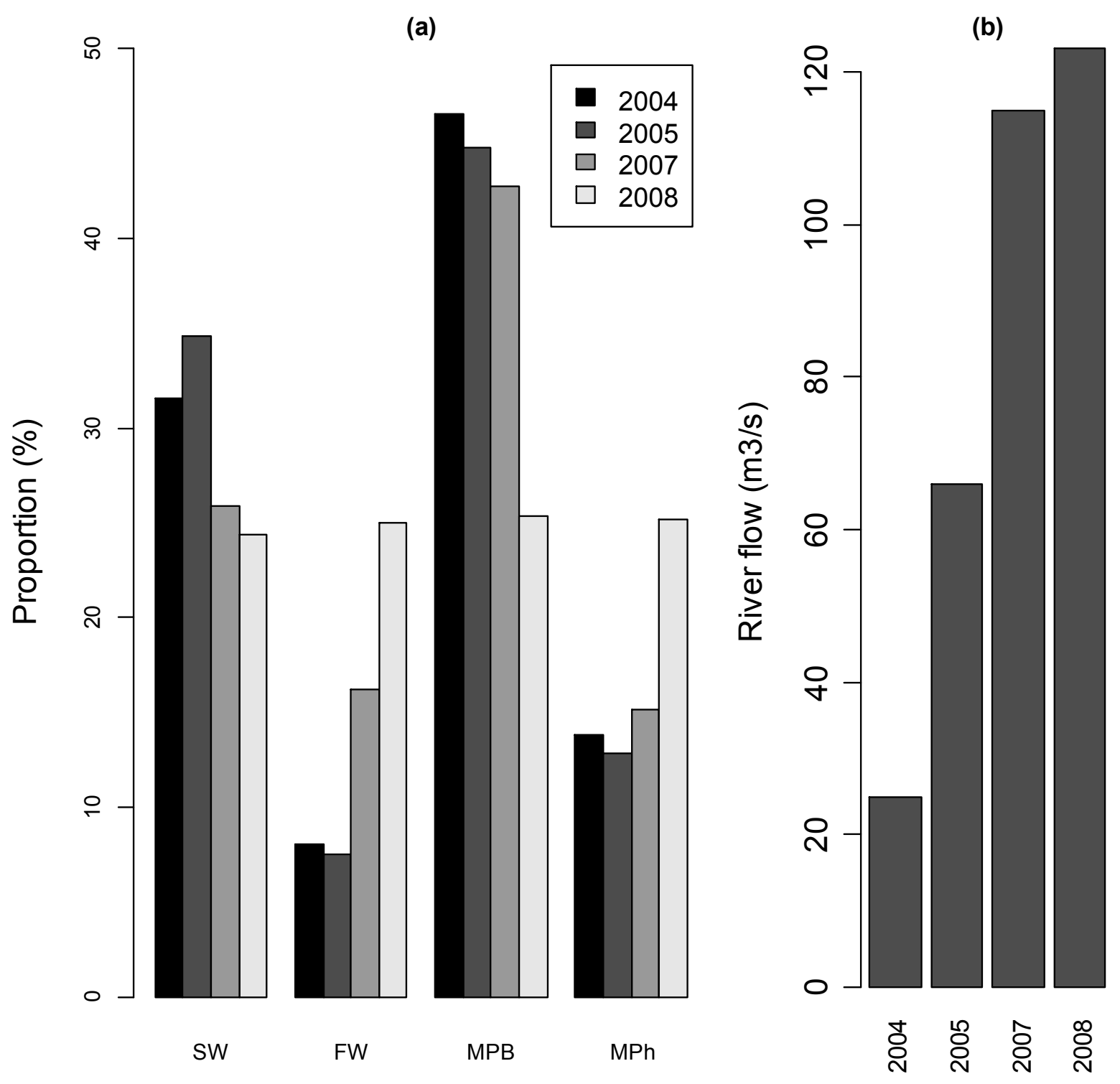
Fig. 5. Average contribution (in \%) of organic matter sources to YoY trophic chain on the 5 studied nursery sectors

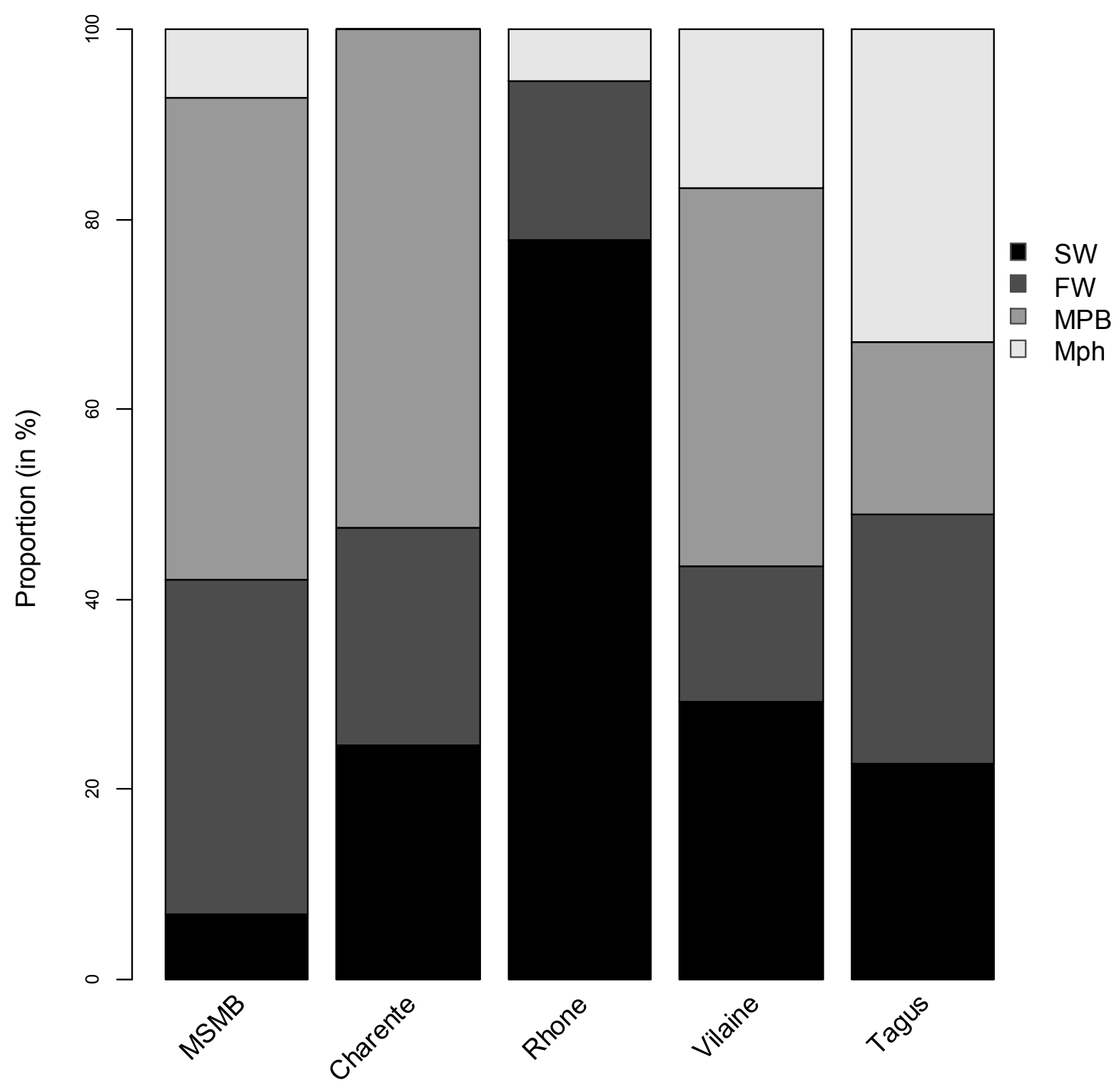


Fig. 6. Contribution (in \%) of the different organic matter sources to YoY trophic chain with relation to log-transformed average river flow $\left(\mathrm{m}^{3} . \mathrm{s}^{-1}\right)$.
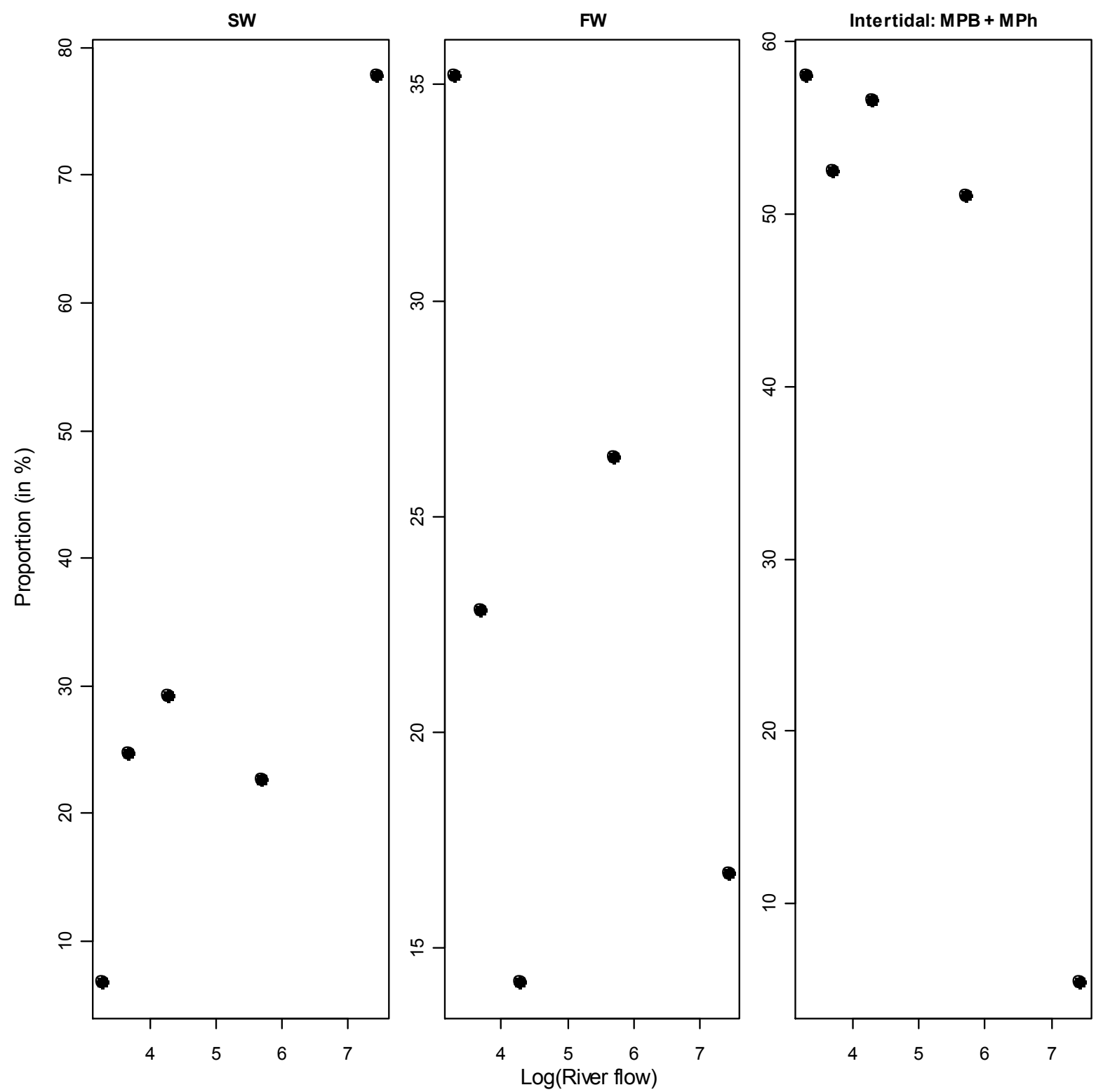
Fig. 7. Contribution (in \%) of the different organic matter sources to YoY trophic chain with relation to the proportion of intertidal surface (in classes of percentage: 1 [0\%, 20\%], 2 [20\%, $40 \%], 3[40 \%, 60 \%], 4[60 \%, 80 \%])$.
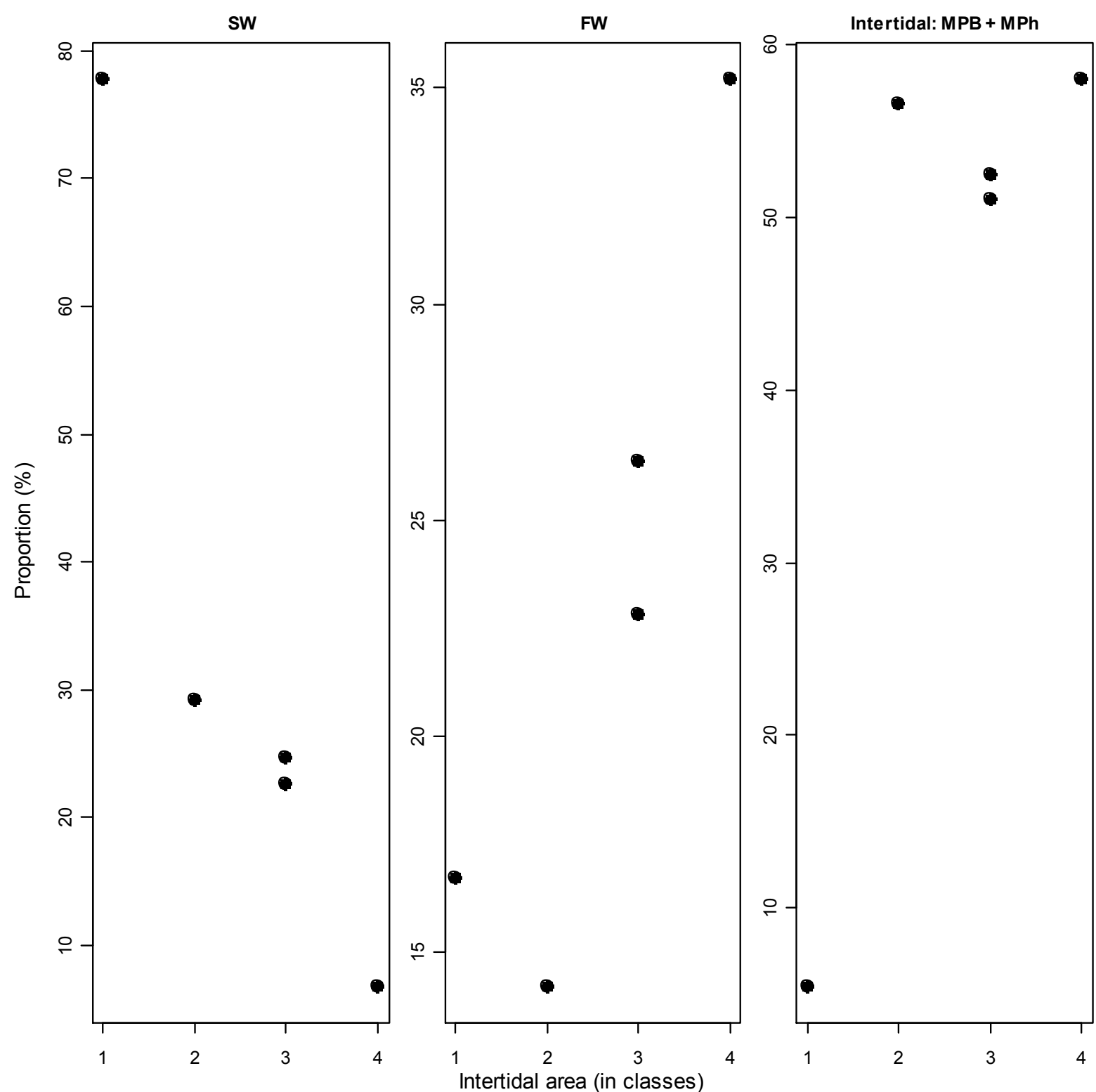